\title{
РАСПУШТАҢЕ РЕДАКЦИЈЕ ЧАСОПИСА НОВИ СВИЈЕТ НАКОН ОБЈАВЉИВАЊА ЈЕДНОГ ДАНА ИВАНА ДЕНИСОВИЧА
}

Износећи и тумачећи историјске документе, записе, дневнике писаца и мемоаре добијамо увид у развој часописа Нови свијет (Новый мир), темеље на којима је часопис постављен, узроке напада на редакцију часописа и њено коначно распуштање. Посебну пажњу скрећемо на догађаје након објављивања Солжењицинове приповијетке Један дан Ивана Денисовича, одлуке донесене на конгресима Комунистичке партије Совјетског савеза (КПСС), те нападе и полемике које су се развиле међу актуелним часописима тога времена. Циљ овога рада је утврђивање позиције, коју је Нови свијет имао 60-тих година XX вијека као значајан симбол епохе отопљења, као и узрока за распуштање редакције часописа.

Кључне ријечи: распуштање редакције, Нови свијет, Један дан Ивана Денисовича, А. И. Солжењицин, А. Т. Твардовски, отопљење.

Through the presentation and interpretation of historical documents, notes, writers' diaries and memoirs, we can obtain insight into the development of the New world (Новый мир) magazine, its foundations and the reasons for the raid on the magazine's editorial office and its eventual dissolution. We draw special attention to the events after Solzhenitsyn's novel A day in the life of Ivan Denisovich was published, the decisions made at the congresses of the Communist party of the Soviet Union (КПСC), as well as the attacks and controversies that developed among magazines at the time. The main goal of this work is to determine the position held by New world in the 1960s as an important symbol of the period of ottepel, its creation and its gradual extinction, as well as the reason for the dissolution of the magazine's editorial board.

Keywords: editorial board dissolution, New world, A day in the life of Ivan Denisovich, A. I. Solzhenitsyn, A. T. Tvardovsky, ottepel.

\section{1. Увод}

Нови свијет је основан 1925. године као научни, књижевно-умјетнички и политички часопис. Настављајући традицију часописа XIX вијека тежио је ка остваривању принципа истинитости, високог естетског квалитета књижевних текстова и научних публикација.

Нашавши се у средишту историјских збивања у Совјетској Русији педесетих и шездесетих година XX вијека часопис Нови свијет (Новый мир) постао је истовремено и симбол епохе отопљења, водеће књижевне традиције тог времена, али и свједочанство политичких превирања, која су усмјерила ток даљег развоја културе.

Часопис, који је водио А. Т. Твардовски од 1958. до 1970. године, означио је колико најаву, толико и врхунац, али и крах једне епохе, којој ћемо у овом раду посветити посебну пажњу с обзиром на међусобно преплитање социјалнополитичке и умјетничке парадигме, које ће се у наставку рада показати као окидач за распуштање редакције поменутог часописа. 
Како бисмо сагледали разлоге због којих су предузете мјере против часописа након објављивања Једног дана Ивана Денисовича (Один день Ивана Денисовича), указаћемо на неколико, по нашем мишљењу, истакнутих обиљежја периода отопљења и начела на којима је Нови свијет заснивао своју дјелатност. Тако Миливоје Јовановић отопљење посматра кроз двије фазе и то: у првој фази означеној од 1953. до 1965/1967. године „траје процес 'отопљења', са свим карактеристикама ослобађања од нормативног погледа на реалност, инсистирања на 'целој истини' о животу садашњости и прошлости, детаљног истраживања друштвено-историјских и политичких основа Стаљиновог времена. [...] У другој, пак, фази под утицајем измењене књижевно-политичке климе, преовлађује став према коме је о недостацима епохе 'култа личности' све речено, а о збивањима савремености треба писати са становишта њихове 'позитивне' перспективе; услед тога се аналитичка проза повлачи или потпада под негативну оцену критике, а у 'магистралне' токове се пробијају синтетичка дела већих облика, закључно са романом-епопејом новог типа“ (Jovanović 1980: 286). Водећи рачуна о томе да су границе двије фазе отопљења о којима Јовановић говори условно постављене, ми ћемо ипак у раду указати на податке који освјетљавају почетак шездесетих година, у оквиру којих се могу препознати противрјечности у односу партије према умјетницима. Тако се граница може повући у 1962/1963. години. Узроке притисака и напада средином шездесетих година треба тражити у одлукама донесеним након XXII конгреса КПСС, а у вези са начелима XX конгреса, што се најприје одразило на објављивање Солжењицинове приповијетке, те на однос према авангардним умјетницима и појединим сарадницима Новог свијета.

Стање у којем се нашла култура у СССР-у шездесетих година ХХ вијека умногоме је дефинисано на ХХ конгресу КПСС одржаном 14. фебруара 1956. године у оквиру којег је наступио и Н. С. Хрушчов са сада већ историјским рефератом. У његовом излагању, усмјереном против култа личности, Стаљин се оцјењује као „изопачење принципа партије и демократије, револуционарних законитости“, а о самом култу се говори да је „попримио чудовишне размјере“1 (Хрущев, интернет). Насупрот томе вођа партије се окреће ка лењинизму и марксизму као јединим прихватљивим обиљежјима развоја друштва. „Звјездани час“" (Ратковский и др. 2001: 147) или врхунац културног преображаја за вријеме отопљења трајао је до тренутка када је доведена у питање и позиција власти актуелне почетком шездесетих година. Упркос најављеном заокрету отопљење се ипак карактерише јаком контролом власти у којој се стваралачка слобода испољавала у одређеним границама.

Након што је одређен систем вриједности и начела по којима се остварује напредак културе, Нови свијет је иступио као либерални часопис у чијим се мјесечним издањима објављују дјела са тематиком приказивања објективне и истините човјекове егзистенције. Инсистирали су на одређивању улоге појединца у стварању историје, приказивали су проблеме друштвено-социјалног типа и без „уљепшавања стварности“. Мада критикован, чланак В. Померанцева O ис-

1 За потребе овога чланка аутор текста је превео са руског на српски цитате извора и литературе. 
крености у књижевности (Об искренности в литературе), објављен у дванаестом броју часописа за 1953. годину, јасно је ударио темеље за формирање идеолошке и културне струје којом је обухваћен и развој Новог свијета до 1970. године. Аутор успоставља знак једнакости између појмова таленат и истина, и сам инсистирајући на начелима истинитости и објективног приказивања свијета стварности и свијета текста на којима се, како смо већ поменули, и заснива тзв. поетика Новог свијета: „За настанак ствари потребан је таленат, тј. у првом реду искреност“ (Померанцев, интернет).

Пратећи развојни пут часописа Нови свијет шездесетих година XX вијека који доводи до распуштања редакције и коначног разрјешења дужности Твардовског са мјеста главног уредника, не можемо занемарити идеолошку позадину која је у то вријеме била у уској вези са књижевношћу, идејама којима се сам часопис водио, те са тим циљем и износимо одређен број биљежака и докумената тога времена, прије свега мемоаре Солжењицина, радне биљешке Твардовског и дневник В. Ј. Лакшина, сарадника у Новом свијету. Рад даје увид у чланке неколико часописа са којима је Нови свијет водио полемику, те одлуке КПСС и Савеза писаца које су значајно одредиле историју часописа и довеле до смјене редакције 1970. године.

\section{2. Један дан Ивана Денисовича - за и против}

Солжењицинова приповијетка Један дан Ивана Денисовича објављена је у једанаестом броју Новог свијета 1962. године. У мемоарима Солжењицина налазимо да је Лакшин вјеровао да се „историја књижевности сад одвија управо у 'Новом свијету', а не у Институту за свјетску књижевност“ (Лакшин према Солженицын 1996: 99) па је тако Нови свијет симболично, према свом називу, постао не само вјесник, него и директни учесник у стварању новог свијета и нове идеологије. Постао је предводник епохе отопљења, показавши примјену начела успостављених на XX конгресу КПСС. То је било прво у низу дјела које је проговорило на тему стаљинистичког терора и директно било усмјерено против социјалистичког тоталитаризма. Таква једна приповијетка логорске тематике не би била одобрена да се нису донијеле мјере које су рушиле култ Стаљинове личности, те је отопљење дочекано са извјесним степеном оптимизма, вјере у моћ ријечи и слободу израза.

Рукопис приповијетке је 1961. године стигао у редакцију Новог свијета, након чега је Твардовски, вјерујући у „промјену свијести“ и да је Солжењицин овим дјелом „уписао своје име у историју совјетске књижевности“ (Твардовский, интернет), послао примјерак приповијетке В. С. Лебедеву, савјетнику Хрушчова за културу, као и писмо самом Хрушчову са молбом да размотри могућност објављивања Једног дана Ивана Денисовича (Солженицын 1996: 36). Хрушчов је о самој приповијетки рекао сљедеће: „То је дјело, које оснажује живот. Рећи ћу чак и више - то је дјело партије. Да је ово написано са мање талента, то би била можда погрешна ствар, али овако, као што је сад, оно мора бити корисно“ (Хрущев, према Лакшин 1991: 75). На тај начин једно партијско остварење, како га и назива Хрушчов, служи као примјер оваплоћења идеја изложених на XX конгресу партије 1956. године, усмјерених против култа личности и заснованих на принципу објективности и документа. Међутим, ту се може наслутити претпоставка да књижевност постаје призната, уколико има пристанак и 
одобрење партије, што се начелно сукобљава са идејом слободне умјетности чији развој мора да егзистира ван оквира било какве идеологије. Књижевни текст постоји и развија се по унутрашњем осјећању аутора и према имагинацији ствараоца. Тако се још једном књижевност нашла на прагу слободне и ангажоване умјетности, као што је то био случај тридесетих и четрдесетих година. За национално добро умјетници и други дјелатници дужни су спроводити мјере и принципе партије.

Упркос одушевљењу које је Хрушчов показао и након публикације Солжењицинове приповијетке, која је најавила отопљење, постоји снажан притисак цензуре. Свако је дјело прије објављивања пролазило контролу, многи су дијелови у различитим текстовима били уклоњени, уколико су изазивали и најмању сумњу. Насупрот идејама слободне мисли и оптимизма којима је обојено отопљење примјећују се границе у оквиру којих власт спутава и контролише све нивое културе, при чему је цензура на челу са Главлитом ${ }^{2}$, „пеживјели орган, који нам је остао у насљедство од култа личности“ (Твардовский, према Лакшин 1991: 76). Твардовски, свјестан притиска цензуре на часопис, који није желио да се одрекне својих принципа, те да многи аутори, а у том реду и Солжењицин, неће моћи објавити своја дјела, покушао је у неколико наврата да утиче на Хрушчова, да издејствује ублажавање, па чак и укидање цензуре. Тако, у Лакшиновом дневнику из 1962. године налазимо: „Од јутра је Твардовски јако ватрено говорио о цензури, о томе да жели да се види са Хрушчовом и да га наговори да цензура књижевних дјела мора бити укинута“" (Лакшин 1991: 68). Убрзо након објављивања Једног дана Ивана Денисовича појавио се читав низ коментара опозиционог карактера, те се могу формирати два супротстављена табора од којих је један „изражавао 'хвала од срца' за истиниту причу, а други су показивали недоумице поводом публикације [...] Солжењицинова приповијетка је просјечно, неталентовано дјело, нешто налик на књижевни куриозитет“ (Ратковский и др. 2001: 154).

\section{3. Противрјечност политике партије и Нови свијет}

Да се „развој културе током 'деценије власти Хрушчова' одвијао у значајној мјери под утицајем политичких реформи“ (исто 2001: 153) иде у прилог чињеници да се тежило остваривању мјера које је прије свега донијела власт, успостављајући контролу над различитим видовима културе, понајвише над умјетношћу и поред тога што се осјетио процват културе почетком отопљења. Конгреси партије (XX, XXII, XXIII) указују да се сходно одлукама закљученим у оквиру њих и обликовала идеологија времена. До двадесетог конгреса 1956. године сваки покушај усмјерен против тоталитаризма оцијењен је као директни напад на партију и сурово је кажњен. Од тада па све до 1962. године могао се примијетити пораст интересовања за теме Стаљинове епохе, те аутори нису презали од оштре критике.

Међутим, почетком шездесетих година осјећа се извјесна противрјечност међу начелима којима се водила власт. Та се противрјечност показала, према нашем мишљењу, најприје на примјеру Солжењицинове приповијетке, а затим

${ }^{2}$ Главное управление по делам литературы и издательств: Главна управа за питања књижевности и издаваштва. 
се одразила и на Нови свијет и поједине ауторе, сараднике редакције, с обзиром на то да су били либерали, који су сврху свог постојања и видјели у изношењу истине, изражавању слободе мисли. Умјетници, окупљени око Новог свијета, директно или индиректно су указивали на проблеме живота, често повезане са догађајима у Совјетском Савезу.

Цензура ${ }^{3}$ се није само сукобила са Солжењицином против Једног дана Ивана Денисовича, него и са другим писцима који су били сарадници Новог свијета у првом реду са И. Еренбургом, А. Возњесенским, В. Њекрасовом и Ј. Јевтушенком. Они су критиковани на првом састанаку Хрушчова са умјетницима, који се збио 17. децембра 1962. године и то: Еренбург за мемоаре, а Њекрасов за биљешке објављене у Новом свијету (Лакшин 1991: 92). Хрушчов директно показује своје незадовољство Еренбургом и Њекрасовом, а самим тим упућује критику Новом свијету, алудирајући да су представници лијеве умјетности и противници партије: „Као што се види, аутор мемоара се са великом симпатијом односи према представницима тзв. 'лијеве' умјетности и ставиће испред себе задатак да заштити ту умјетност. Поставља се питање од кога да заштити? Изгледа од наше марксистичко-лењинске критике. [...] Друг Еренбург чини грубу идеолошку грешку и наша је дужност да му помогнемо да то схвати“ (Хрущев према Лакшин 1991: 109). Овако је показано неповјерење према часопису Твардовског за који је једини исправан пут био пут истине, књижевности и знања који не зависи од правила водеће идеологије. Твардовски ће изјавити поводом напада на Еренбурга да су му само признали таленат упућујући критику на рачун његовог стваралаштва (Твардовский према Лакшин 1991: 128), прије свега имајући на уму таленат који не преза од истинске умјетности, којој се супротставља идеологија.

Прве знакове рушења епохе отопљења и часописа Нови свијет треба тражити на почетку шездесетих година. Све што ће се десити од 1965. године до 1970. само је посљедица, односно резултат свих поменутих догађаја, односно мјера које је покренула партија у обрачунавању са противницима патриотизма. Да власт намјерава ограничити успон авангардног утицаја и тиме спријечити губитак контроле над културом, показало се 1962. године у мјесецу децембру након изложбе у Мањежу, коју је посјетио Хрушчов. Његово неразумијевање, нетрпељивост, па чак и бојазан од свега новог, зачуђујућег, бунтовничког испољили су се у вези са овом изложбом. Многе од слика које је те вечери Хрушчов исмијао сутрадан су биле уклоњене («Посещение Н. С. Хрущевим выставки художников-авангардистов в Манеже», интернет). Између осталог, говоримо о сликама модерниста Павла Кузњецова, Роберта Фаљка, те сликама познатих авангардиста - ученика Е. Бељутина, чији се умјетнички правац заснива на духовном преображају путем умјетности (исто, интернет).

Прва у низу мјера спроведена је наредне 1963. године у неколико наврата, када се покушало са спречавањем и обустављањем објављивања појединих бројева

\footnotetext{
3 Лакшин биљежи да је главни цензор Новог свијета био Виктор Голованов, чије је радне биљешке добио седамдесетих година 20. вијека након његове смрти. Сарадници Голованова су били стаљинисти Г. К. Семенова, А. С. Петрович, Р. П. Константинович (Лакшин 1991: $77,78)$.
} 
часописа. Тако је због сумњивог карактера доведен у питање и четврти број из којег су избацили Камијеву Кугу (Чума) Чанку (Чанка) Х. Гојтисоле, Други ешалон (Второй эшелон) Е. Ржевске, Е. Габриловићеву Из прошлости (Из прошлого) (Голованов према: Лакшин 1991: 123). У биљешкама главног рецензента Лакшин проналази разговор између Голованова и А. Дементјева, тадашњег замјеника главног уредника, у којем А. Дементјев показује своје незадовољство због задржавања четвртог броја: „Прошло је много времена, а од вас никаквих обавјештења - са чим сте сагласни, а са чим не. [...] Ево шта се дешава дајемо часопис цензури, а од ње готово никаквих конкретних примједби и упутстава, а ако их и добијемо то је у ЦК КПСС““ (Голованов према Лакшин 1991: 126). Тако је и шести број часописа 1964. године био готово забрањен у потпуности, као и поновно штампање Некрасовљевог Мјесеца у Франиуској (Месяи во Франции) у којем су цензори видјели алузију на проблем штампања дјела у часописима у СССР-у (Лакшин 1991: 238, 239). Еренбург је још једанпут оптужен за мемоаре ,због јеврејског питања“" (исто 1991: 251).

Часопис Нови свијет је у 10. броју за мјесец октобар 1964. године објавио обраћање редакције (Om редакции) у којем се одређује пут часописа, дајући предност дубинској анализи живота и високој духовној култури у односу на површност и идеолошку пристрасност: „Али ми увијек тежимо и тежићемо да избјегнемо било коју врсту фалсификовања књижевности, површну и илустративну белетристику, сматрајући основном вриједношћу дјела непосредну истину живота, моћ писца да постигне ту дубину, идејну принципијелност. [...] Зато сматрамо и сматраћемо својим дугом борбу против илустративности, књижевне беспринципијелности, сивила, ниског културног нивоа“" (исто 1991: 164). Исте године у десетом мјесецу Лакшин биљежи забринутост Твардовског за судбину часописа: „Нашли смо се у центру пажње у посљедње двије године. Никада нисам то претпостављао, нисам о томе хтио да размишљам. Са осмијехом на лицу сам гледао борбу [...] Али су нас услови поставили у центар пажње“ (Твардовский према Лакшин 1991: 253, 254). И заиста, притисак се одразио на редакцију и сараднике часописа упркос томе што су и Твардовски, као уредник, и сарадници Новог свијета покушавали да се изборе за штампање часописа.

Велику пажњује изазвао чланак Лакшина Иван Денисович-његови пријатељи и непријатељи (Иван Денисович, его друзья и недруги, 1964). Чланак говори о критикама доспјелим на адресу Солжењицина поводом објављивања поменуте приповијетке. Неколико текстова се појављује као одговор на Лакшинов чланак, при чему од Кьижевних новина (Литературная газета) долазе замјерке на рачун самог аутора чланка, оцјењујући га површно и непријатељски. Пребацују му једностраност, да се усмјерио само на опаске поводом Једног дана Ивана Денисовича, да је занемарио позитивну критику, те да се негативно односи према свему што указује на мане самог јунака (Лакшин 1991: 198).

Четрдесету годишњицу рада часопис је обиљежио у јануару 1965. године. Тим поводом Твардовски је написао чланак Поводом јубилеја (По случаю юбилея) који је наишао на оштру критику часописа прије свега противника Новог свијета, али и партије. Твардовски је поменуо писце и дјела које цензура није допустила. Још једном је окривио партију и цензуру за мијешање у књижевност: „Часопис је рушио принцип једномишља и слијепе идеолошке покорности. За 
конзервативце је била важна, не толико суштина дјела, колико нерушива архитектура књижевног утврђења, чији је темељ била оданост партији, зидови су му сложени од народности, а кров је био социјалистички режим“ (исто 1991: 262).

Не само да је партија нападала часопис у раним шездесетим годинама, него су то неријетко чинили и многи часописи. Готово свакодневно су излазили чланци у којима су се могле пронаћи критике на рачун позиције Новог свијета. А. Сурков у чланку Из реферата са скупа (Из отчёта о собрании), објављеном у Къижевним новинама 19. марта 1963. године, износи сумњу у исправност васпитне позиције Новог свијета: „Задатак совјетских писаца је васпитање омладине на позитивним примјерима, њихово вођење ка свијетлој будућности, ка комунизму [...] Са те тачке гледишта није ми јасно коју позицију заузима часопис 'Нови свијет"“ (Сурков према Лакшин 1991: 110). Тако и С. Павлов у чланку Стваралаштво младих је служење великим идеалима (Творчество молодых - служению великим идеалам), објављеном у Комсомољској истини (Комсомольская правда) 22. марта 1963. године, набраја књиге Еренбурга, Јашуна, Њекрасова, Аксјонова, Солжењицина, истичући да „одишу таквим песимизмом, трулошћу, безизлазношћу [...] Узгред, слична дјела 'Нови свијет' штампа са потпуно необјашњивом досљедношћу“ (Павлов према Лакшин 1991: 111).

Критике новина и часописа упућене на адресу Новог свијета износе прије свега оптужбе на рачун недосљедности и непоштовања партијских начела, показивања бунта који отежава напредак ка комунистичком друштву. Као што се да примијетити, у већ поменутим биљешкама Лакшина, многа дјела бивају забрањена, појачава се провјеравање писаца, одузимање рукописа.

Још једним чланком Шта је праведност? (Что есть справедливость?), који је објављен 31. августа 1963. године усмјерили су се против Новог свијета, овај пут против Солжењицинове приповијетке За корист ствари (Для пользы дела). J. Барабаш замјера Солжењицину архаичност и обраду питања мимо реалних услова живота (Барабаш према Лакшин 1991: 161). Солжењицин је, осјећајући страх од шпијунирања и претреса, често ноћу провјеравао да ли је све рукописе добро сакрио (Солженицын 1996: 18). Изразита сумња и неповјерење према овом писцу огледа се у немогућности да објављује своје радове. Од 1963. до 1966. године Солжењицин је издао свега три дјела и то: Догађај на станищи Кречетовка ( Случай на станциии Кречетовка, Новый мир, º1, 1963), За корист ствари (Для пользы дела, Новый мир, №7, 1963) и Захар-Калиту (Захар-Калита, Новыц мир, $\left.\mathrm{N}^{\circ} 1,1966\right)$, («Александр Исаевич Солженицын. Биографические справки», интернет).

Поводом XXII конгреса КПСС одржаног 1961. године Солжењицин биљежи: „А ту је на XXII конгресу још наступио и Твардовски са таквом нотом, да одавно можемо штампати смјелије и слободније, а ми то не чинимо“ (Солженицын 1996: 20). Твардовски тако подсјећа да се мјере донесене 1956. године не спроводе у свим оквирима, да постоје извјесни застоји у приказивању истине живота, на шта, сложићемо се, указују и бројне критике упућене на рачун умјетника који одступају од прогресивног напретка партије. Те 1961. године на XXII конгресу партије донесене су одлуке о развоју и дјеловању партије у различитим сегментима привредног и културног развоја. Међутим, читав низ мјера 
укључујући и „програм за грађење комунистичког друштва СССР“ (Ратковский и др. 2001: 151), одразиле су се на културу и биле су знатно супротстављене политици, коју су формирали 1956. године, када је интелигенција осјетила наду у могућност духовног развоја (исто 2001: 153). У првом реду ограничена је слобода писања у којој се предност даје ангажованој умјетности, чија дјела правилно васпитају карактер друштва. Зато Твардовски и пише сљедеће: „Јасна ми је позиција тих кадрова. Они су досљедни и нерушиви, упркос ономе о чему је било ријечи на последњем конгресу и чак на посљедњем пленуму ЦК“ (Твардовский, интернет). Није на одмет напоменути да су се након овог конгреса 1961. године критике појачале против свих који су показали непоштовање поменутих начела, што ће се и видјети у наставку рада.

На засиједању ЦК КПСС 1964. године, осим А. Твардовског присуствовао је и А. И. Кондратович, замјеник уредника Новог свијета. Још је тада указано на ривалство између Новог свијета и Октобра 4 (Октябрь), у којем једна страна заузима прогресивну, а друга конзервативну страну (Ильичев према Лакшин 1991: 230). На челу часописа Октобар био је В. Кочетов „који се стално борио против либералних тенденција часописа 'Нови свијет', учинивши О. правим ослонцем конзерватизма у сов. књижевности [...] О. је увијек остајао вјеран својим принципима, чија се суштина састојала у томе да је књижевност позвана да служи само као илустрација одговарајуће политике партије“ (Казак 1988: 552). На томе се и заснива позиција коју су заузела два часописа, али и сукоб у којем ће један тежити ка либерализму, а други ка рехабилитацији култа личности. У овоме се сукобу заправо огледала читава културна сцена шездесетих година у којој ће једни стати на страну досљедног праћења ангажоване умјетности, док ће други бити на страни непосредног стваралачког чина, којег не спутавају законитости политичко-друштвеног типа.

Након смјене Хрушчова 1964. године дошло је до политичког и културног заокрета. Са Л. И. Брежњевом на власти услиједиле су, како ће се и показати, године великог притиска на друштво, нарочито на умјетност и културу. Те исте године спроведене су прве кампање против Ј. Бродског, а затим ће услиједити процес против Б. Пастернака, А. Сињавског и Ј. Данијела. На листи непожељних аутора нашли су се и А. Ахматова и Ј. Јевтушенко. Власт се на овај начин сукобила и обрачунавала са интелектуалцима који су својим дјелима изражавали негативан став према Стаљиновој епоси и актуелним питањима њиховог времена. Солжењицин је оптужен за клевету Стаљинове личности, за савезништво са Нијемцима (Солженицын 1996: 92). Да апсурд буде већи 1964. године он није добио Лењинову награду, јер је против кандидатуре гласао већи број чланова Савеза писаца, док су представници филма и драматургије гласали за Солжењицина (исто 1996: 91). Он сматра да су организовали тајно гласање у којем је већ наглашено да се гласа против његове кандидатуре: „Пред само тајно гласање још су одвојено обавезали партијску групу унутар комитета да гласају против моје кандидатуре““ (исто 1996: 92).

\footnotetext{
${ }^{4}$ Часопис Октобар је основан 1924. године у Москви као орган МАПП-а (Московска организација пролетерских писаца).
} 


\section{4. Распуштање редакције часописа Нови свијет}

Друга половина шездесетих година карактерише се појачаним притиском партије, Савеза писаца и појединих часописа на редакцију Новог свијета, на шта указује и Т. Остроумова, подвлачећи да се „положај часописа погоршао након угушивања 'Прашког прољећа'“ (Остроумова 2018: 603). Извршен је читав низ кључних мјера против Солжењицина, Твардовског и Новог свијета са циљем слабљења њихове позиције, што ће коначно и резултирати распуштањем редакције.

Прије свега велику пажњу на књижевној сцени изазвали су Солжењицинови романи Одјељење за рак (Раковый корпус) и $У$ кругу првом (В круге первом). Напомињемо да су ова дјела објављена по први пут у Русији тек 1990. године. Управо су она разлог због кога се Нови свијет све чешће напада за сарадњу са Западом. Истакнућемо да је прије свега забрањена било каква публикација ових дјела у часописима у Русији, да би се затим ширила по самиздату, што је представљало лошу позицију за писце, који су користили овакав илегални пут издавања. Међутим, то је и те како послужило повећању напада на часопис, што ће кулминирати, како ћемо видјети, објављивањем поеме Правом памћења (По праву памяти) Твардовског 1969. године и Писма једанаесторице (Письмо одиннадиати, 1969). Ако се прва половина шездесетих година карактерише тек објављивањем појединачних чланака прије свега критика на рачун Солжењицина и других аутора, сарадника Новог свијета, друга половина шездесетих година је обиљежена учесталијим и агресивнијим штампањем чланака и писама упућених на рачун редакције часописа.

Одјељеље за рак држали су у сефу Новог свијета ради сигурности и према наређењу Твардовског: „У 'Новом свијету' од трена кад су добили 'Одјељење за рак' направили су од њега тајни документ, тако је одредио Твардовски“ (Солженицын 1996: 143). Упркос томе што је он сматрао да није право вријеме да се објави дјело, Солжењицин је те 1966. године послао писмо Брежњеву са молбом да му дозволи штампање романа, на које Брежњев није одговорио (исто 1996: 150, 172). Познато је да у том моменту нису били добри односи између Солжењицина и Твардовског због неслагања у вези са Одјељењем за рак. Насупрот упорности Солжењицина да под сваку цијену објави роман, Твардовски је сматрао да је најбоље сачекати, јер је у том тренутку притисак на часопис био огроман (исто 1996: 143).

У мају 1967. године Солжењицин је упутио писмо IV конгресу Савеза писаца у којем је изразио негодовање поводом забране штампања његових дјела у Русији. У том писму Солжењицин заправо не показује само свој став према Савезу у вези са романом који треба објавити, него и објашњава стање у умјетности наглашавајући потребу партије да се мијеша у књижевност и тако управља естетским начелима: „Књижевност се не смије развијати у категоријама хоћемо пустити - нећемо пустити. Предлажем Савезу да испуни захтјев и да укине сваку — јавну или тајну — цензуру над умјетничким дјелима, да ослободи издаваштво од обавезе да тражи дозволу за сваки лист штампе“ (исто 1996: 598).

Лакшин и Твардовски, мада скептичан због теме самог дјела, предложили су да се неколико поглавља Одјељења за рак штампа у Књижевним новинама, те 
је редакција и одлучила да објави неколико глава поменутог дјела (исто 1996: 175-176, 191). На сједницама које је организовао Савез често су разматрана Солжењицинова дјела и поступци. Нашавши се на граници између књижевности и политике, контроле и слободе он истиче да „послије 'Ивана Денисовича' по староме нико више не пише и то изазива противљење власти“ (исто 1996: 198). Наредне 1968. године Солжењицинове претпоставке, али и упозорења која је упутио Савезу писаца поводом Одјељена за рак су се обистиниле. Док су у Русији одуговлачили са штампањем романа, изразито забрањујући Новом свијету да објави Одјељење за рак (исто 1996: 601, 631), дијелови романа су се нашли на Западу у самиздату 1968. године у књижевном додатку Tajмca (исто 1996: 618). Међутим, нешто прије тога објављена је прва глава романа у Чехословачкој у часопису Истина (Правда). Солжењицин, као и нешто касније Твардовски, није дозволио да се објави роман на Западу, иако су гласине, а затим и мјере власти показале другачије. Из тог разлога Солжењицин је написао писмо редакцијама часописа Монд (Монд), Унита (Унита) и Кюижевним новинама у којем изјављује да није дозволио, нити ће дозволити штампање Одјељења за рак: „зато ничију [...] публикацију не признајем важећом, никоме не признајем издавачка права; свако кварење текста [...] наноси ми штету; сваку самовољну екранизацију и инсценацију одлучно поричем и забрањујем“ (исто 1996: 619). Часопис Границе (Грани) послао је писмо Солжењицину у којем га обавјештавају о објављивању романа на Западу, наглашавајући да је за то одговоран Комитет државне безбједности: „Обавјештавамо Вас да је Комитет државне безбједности преко Виктора Луи послао на Запад још један примјерак Одјељења за рак, да би тако блокирао његову публикацију у 'Новом свијету'. Зато смо ријешили да то дјело објавимо одмах“ (исто 1996: 202). Виктор Луи (Виктор Левин) био је кореспондент деснице и сарадник енглеских новина (исто 1996: 205). У Русији је то изазвало велики број напада на часопис, неповјерење партије и чланова Савеза писаца. У Одјељењу за културу ЦК већ су бројали дане Твардовском и Новом свијету (исто 1996: 219). Најзад, Савез писаца у датом роману види одлике антихуманизма (исто 1996: 613). Дијалог између Солжењицина и Савеза писаца често је био узалудан. Са једне стране, стајао је Савез који је имао јаку намјеру да смањи или у потпуности избјегне објављивање Солжењицинових дјела, а са друге стране, је био Солжењицин упоран у својој намјери да укаже на клевете и штету коју му чине, да укаже на озбиљан проблем културе.

Од 1967. године бројеви часописа све рјеђе излазе. Готово да у потпуности забрањују поједине бројеве, који ионако бивају преполовљени (Тазеева 2008: 177). Све што је носило обиљежје контрареволуције и одисало опасношћу било је избачено из часописа. У том хаосу Твардовски се све више повлачио у себе, постајао раздражљив. Према ријечима Солжењицина „Твардовски је био кисео и мрачан“"(Солжењицын 1996: 176). С тим у вези истакнућемо да је државни врх поништио његову кандидатуру у Академију наука, као и да га нису изабрали у Врховни савјет РСФСР на XXIII конгресу партије 1966. године (исто 1996: 160). Тиме су га покушали лишити могућности да директно учествује у доношењу одлука власти и да измијени позицију Новог свијета. Његова су дјела све рјеђе пролазила цензуру и бивала објављена због сумње да критикује 
власт. Тако ћемо и сазнати, захваљујући биљешкама Солжењицина, да је Твардовски часопис волио насупрот томе што су његова дјела излазила све рјеђе (исто 1996: 223). Пјесма На сењаку (На сеновале) прерасла је у поему Правом cјећаға. Упркос томе што је била забрањена, као и роман Солжењицина, поема Твардовског појављује се на Западу 1969. године у часопису Усјев (Посев) као „злурада, недовршена, позна гордост и чемер аутора коју није прихватила ни власт, ни публика [...] Твардовски је био потресен, обесхрабрен, потиштен“ (исто 1996: 257). Крај Новог свијета био је неизбјежан.

Убрзо након овога (4. новембар 1969. године) сазвана је сједница Савеза писаца у Рјазању на којој су донијели одлуку о избацивању Солжењицина из Савеза. У исто вријеме у Москви оптужени су Б. Окуџава, Л. Чуковска и Л. Копељев (исто 1996: 245). Солжењицин, огорчен неправдом, послао је отворено писмо Савезу писаца у којем не само да оптужује Савез за неосновано избацивање из удружења, него упућује на озбиљне друштвене проблеме у којима се нашао СССР. Солжењицин сматра да се питања умјетности не могу рјешавати на начин ,држати и не пуштати!“ (исто 1996: 628) и да Савез мора преузети одговорност за своје поступке. Пребацује им сакривање чињеница, удаљавање од основних начела умјетности, прије свега изражавања гласног изговарања мисли: „Отвореност, поштена и потпуна отвореност је први услов здравља сваког друштва, и нашег наравно“ (исто 1996: 629).

Међутим, ништа није тако снажно одјекнуло и одредило крај Новог свијета као чланак Против чега иступа Нови свијет (Против чего выступпает Новый мир), познат још као Писмо једанаесторице 5 , које је објављено у часопису Пламичак (Огонёк) 26. јула 1969. године. Поредећи тираж Новог свијета и Пламичка Н. Тазејева истиче да је поменути чланак изашао из штампе у 2125 000 примјерака, без кашњења за разлику од Новог свијета, којем публикација мјесечних издања тих година није била редовна. Совјетски писци су спровели организовану кампању у штампи, појачавајући нетрпељивост према Новом cвијету и борбу супротстављених идеја међу часописима (Твардовска према Тазеева 2008: 180). Нови свијет је у Писму једанаесторицее оптужен за космополитизам, непоштовање патриотизма и приближавање интернационализму («Последние следы спора утопляя в политическом визге. Разгром 'Нового мира'», интернет). Другим ријечима, овако су поступили ,да би се пресјекле истините публикације, које приказују совјетско друштво у лошем свјетлу“ (исто, интернет), односно оне које дају приказ стварности онакве каква јесте, а не каква би требало да буде. Противници упозоравају на штетност напредовања идеологије коју заступа Нови свијет: „Ако се против ње не будемо борили, то може довести до постепеног јачања пролетерског интернационализма тако драгог срцу неких критичара и књижевника, који су се окупили са космополитским идејама око Новог свијета“ (исто, интернет). С обзиром на то да је ослабљена позиција часописа ограничавањем дужности Твардовског и да је часопис већ био критикован за сарадњу са Западом, те лош васпитни утицај,

${ }^{5}$ Као аутори чланка у Пламичку потписали су се: М. Алексејев, С. Викулов, С. Вороњин, В. Загруткин, А. Иванов, С. Малакшин, А. Прокофјев, П. Проскурин, С. Смирнов, В. Чивилихин, Н. Шундук. 
Писмо једанаесторице се испоставило као оштра пријетња и завршни напад који је довео до краха редакције Новог свијета.

„Страсна седмица“ (Твардовский, интернет), како је назива Твардовски, посљедња је недјеља часописа у којој је он водио редакцију. У тих неколико дана мјесеца фебруара 1970. године донесена је одлука о смјени чланова редакције, у првом реду И. Виноградова, В. Лакшина и И. Кондратовича (Солжењицын 1996: 258), на чије ће мјесто доћи други. У знак протеста против смјене читаве редакције Твардовски је одлучио да сам изађе из часописа. Као разлоге због којих је нападнут Нови свијет и извршена смјена кадрова Одјељење за културу ЦК КПСС наводи да су запажене „озбиљне идејне грешке [...] у часопису су се и раније објављивали материјали који су изазвали оштру критику штампе и Савеза писаца СССР“ («Последние следы спора утопляя в политическом визге. Разгром 'Нового мира'», интернет).

Велику забринутост за сопствено стваралаштво показали су многи писци током посљедњих дана Твардовског у часопису. Долазили су по своје рукописе, плашећи се да не буду одузети (Солженицын 1996: 258). Твардовски је написао писмо ЦК КПСС-у у знак протеста против одлуке Бироа Секретаријата. Наиме, одлуку о разрјешењу Твардовског дужности донијели су у Бироу без његове сагласности, одредивши за ту позицију новог уредника («Последние следы спора утопляя в политическом визге. Разгром 'Нового мира'», интернет). Испоставило се касније да је на његово мјесто дошао В. А. Косолапов. Твардовски је наравно био свјестан напада партије још почетком шездесетих година. Упућивао је на посљедице које могу бити погубне за читаву књижевност, умјетност и културу, а које су изазване оштрим поступањем партије, која је након XXXIII конгреса пропагирала стаљинизам, гдје је Брежњев „формално иступио против двије крајности“ (Ратковский и др. 2001: 166). Брежњев није одговорио ни на колективно писмо ${ }^{6}$ совјетских писаца у којем су изразили молбу и протест против смјене редакције: „Сасвим смо увјерени да је за добро читаве совјетске културе неопходно да 'Нови свијет' настави свој рад под руководством А. Т. Твардовског и у том саставу редакције који он сматра корисним за часопис“" («Последние следы спора утопляя в политическом визге. Разгром 'Нового мира'», интернет), тј. писци упућују на грешке које чини партија, а на које је указао и Солжењицин - књижевност и идеологија не путују истим правцем, те је из тог разлога неоправдан поступак власти да смијени чланове редакције за добробит будућег развоја друштва.

Три дана послије одлуке Бироа о распуштању редакције Твардовски одлази са мјеста главног уредника часописа, којем су одузели „његово дјетенце његову страст — његов часопис“ (Солженицын 1996: 636). Тако се одласком Твардовског угасио Нови свијет вођен идејама вјерног и критичког тумачења појава и слободне умјетности са којим је заједно утихнуло и вријеме отопљења.

\footnotetext{
${ }^{6}$ Писмо су потписали: А. Бек, В. Каверин, Б. Можаев, А. Рибак, Ј. Трифонов, А. Вознесенски, Ј. Јевтушенко, М. Алигер, Е. Воробјов, В. Трендјаков, Ј. Нашибин, М. Исаковски. 


\section{5. Закључак}

Постављајући за циљ овога рада утврђивање узрока под којима је распуштена редакција часописа Нови свијет 1970. године, али и њихово разумијевање, посебну смо пажњу обратили на развојни пут часописа шездесетих година XX вијека. У раду смо дали преглед одлука донесених на конгресима ЦК КПСС и Савеза писаца, те чланке различитих часописа и новина, објављиваних током отопљења, у којима се нису подржавала начела редакције Новог свијета. Часопис Твардовског је своју позицију градио у таквој атмосфери у којој се предност давала оним дјелима која су служила као примјер обликовања духовне свијести која обезбјеђује не само напредовање друштва, него и контролу над њим. Тако је Нови свијет критикован због својих либералних, никако антисовјетских публикација у којима књижевност није пружала васпитање друштва на партијским начелима, а похваљен је за она дјела у којима је служио као примјер правилности рјешења партије. С тим у вези показали смо да је редакција Новог свијета распуштена због Писма једанаесторице, објављивања поеме А. Твардовског Правом сјећањ $а$, која је изражавала незадовољство влашћу Брежњева, а такође и Солжењицинових романа У кругу првом и Одјељена за рак у самиздату.

Међутим, да бисмо добили потпуну слику и разумјели шта је довело часопис до смјене редакције, осврнули смо се на почетак шездесетих година, када се по први пут испољила противрјечност у спровођењу одлука партије, која се несумњиво одразила и на сам часопис. Недосљедност власти огледа се, с једне стране, у подржавању интелигенције и умјетности, док то не ремети позицију власти, а са друге стране, у прибјегавању оштрим одлукама, када то доводи у питање могућност контроле над друштвом. Стога смо на почетку рада истакли важност објављивања Једног дана Ивана Денисовича са којим се у центру културних дешавања нашао и Нови свијет чија су се либерална начела у то вријеме подударала са одлукама донесеним на XX конгресу КПСС. Осим Солжењицина и Твардовског оштро су критиковани и остали сарадници часописа од чланова редакције до писаца који су своја дјела објављивали у Новом свијету. Потпуно или дјелимично необјављивање појединих бројева часописа и оштра цензура показали су се као основно средство борбе против часописа, прије него што су предузете директне мјере против појединих аутора. Анализирајући мемоаре, биљешке писаца и документе партије утврдили смо да су све поменуте мјере и одлуке довеле до гашења редакције и одласка А. Твардовског са мјеста главног уредника 1970. године, али је прије свега до смјене редакције дошло због заузимања досљедње позиције, која се огледала у објективности, критичком односу према стварности, истинској вриједности књижевних публикација и која је, најзад, стајала против ангажоване умјетности.

У раду смо поменули нека од најзначајнијих имена која су учествовала у стварању историје часописа Нови свијет. Не желећи да се удаљимо од теме коју смо себи задали за проучавање, тек се назире могућност за даља и детаљнија пручавања односа међу Твардовским и сарадницима Новог свијета која би несумњиво дала нове резултате у погледу развоја унутрашњих тенденција, те потешкоћа на које је наилазио часопис. 


\section{Цитирана литература}

Казак, Вольфганг. Энциклопедический словарь русской литературы с 1917 года, пер. с немецкого Елена Варгафтик и Игорь Бурихин, изд. 2-ое. Лондон: Overseas Publications Interchange Ltd., 1988.

[Kazak, Vol'fgang. Entsiklopedicheskiy slovar' russkoy literatury s 1917 goda, per. s nemetskogo Elena Vargaftik i Igor' Burikhin, izd. 2-oye. London: Overseas Publications Interchange Ltd., 1988.]

Остроумова, Т. О. «Журнал 'Новый мир' А. Т. Твардовского в мемуарах». Обсерватория культуры Т. 15, 5, 2018: 599-607.

[Ostroumova, T. O. «ZHurnal 'Novyy mir' A. T. Tvardovskogo v memuarakh». Observatoriya kul'tury T. 15, 5, 2018: 599-607.]

Ратковский, И. С., М. В. Ходяков. История советской России. Санкт-Петербург: Лань, 2001.

[Ratkovskiy, I. S., M. V. KHodyakov. Istoriya sovetskoy Rossii. Sankt-Peterburg: Lan', 2001.]

Тазеева-Гриценко, Т. Н. «Журнал 'Новый мир' сквозь призму его тиража (1960е гг.)». Вестник РГГУ. Серия: Журналистика. Литературная критика 11, 2008: $171-182$.

[Tazeyeva-Gritsenko, T. N. «ZHurnal 'Novyy mir' skvoz' prizmu ego tirazha (1960-e gg.)». Vestnik RGGU. Seriya: ZHurnalistika. Literaturnaya kritika 11, 2008: 171182.]

Jovanović, Milivoje. Pogled na rusku sovjetsku književnost. Beograd: Prosveta, 1980.

\section{Извори}

«Александр Исаевич Солженицын. Биографическая справка». Риа новости $<\mathrm{https}$ :// ria.ru/20110523/378507746.html > 24.04.2020.

[«Aleksandr Isayevich Solzhenitsyn. Biograficheskaya spravka» Ria Novosti $<$ https://ria. ru/20110523/378507746.html > 24.04.2020]

Лакшин, Владимир. Новый мир во времена Хрущева. Дневник и попутное (19531964). Москва: Книжная палата, 1991.

[Lakshin, Vladimir. Novyy mir vo vremena KHrushcheva. Dnevnik i poputnoye (19531964). Moskva: Knizhnaya palata, 1991]

Померанцев, Владимир. «Об искренности в литературе». Новый мир, $\mathrm{N}^{\circ} 12,1953$ : 218-245. <http://vivovoco.astronet.ru/VV/PAPERS/LITRA/MEMO/POMER.HTM> 22.04.2020.

[Pomerantsev, Vladimir. «Ob iskrennosti v literature». Novyy mir, $\mathrm{N}^{\circ}$ 12, 1953: 218-245. $<$ http://vivovoco.astronet.ru/VV/PAPERS/LITRA/MEMO/POMER.HTM> 22.04.2020]

«Посещение Н. С. Хрущевим выставки художников-авангардистов в Манеже», История РФ $<$ https://histrf.ru/lenta-vremeni/event/view/posieshchieniie-n-s-khrushchievym-vystavki-khudozhnikov-avanghardistov-v-maniezhie $>24.04 .2020$.

[«Poseshcheniye N. S. KHrushchevim vystavki khudozhnikov-avangardistov v Manezhe», Istoriya RF <https://histrf.ru/lenta-vremeni/event/view/posieshchieniie-n-s-khrushchievym-vystavki-khudozhnikov-avanghardistov-v-maniezhie> 24.04.2020] 
«Последние следы спора утопляя в политическом визге», Коммерсантъ, $\mathrm{N}^{\circ} 26$ $<$ https://www.kommersant.ru/doc/2768721> 22.04.2020.

[«Posledniye sledy spora utoplyaya v politicheskom vizge», Kommersant”, No26 < https:// www.kommersant.ru/doc/2768721>22.04.2020]

Солженицын, Александр. Бодался Телёнок с дубом. Очерки литературной жизни. Москва: Согласие, 1996.

[Solzhenitsyn, Aleksandr. Bodalsya Telënok s dubom. Ocherki literaturnoy zhizni. Moskva: Soglasiye, 1996]

Твардовский, Александр. «Рабочие тетради 60-х годов», Знамя, $\mathrm{N}^{\circ} 9<\mathrm{http}$ ://znamlit. $\mathrm{ru} /$ publication.php?id=2442> 21.04.2020.

[Tvardovskiy, Aleksandr. «Rabochiye tetradi 60-kh godov», Znamya, $\mathrm{N}^{\circ} 9<\mathrm{http} / /$ znamlit.ru/publication.php?id=2442> 21.04.2020]

Твардовский, Александр. «Рабочие тетради 60-х годов», Знамя, $\mathrm{N}^{\circ} 11<\mathrm{http}$ ://znamlit. ru/publication.php?id=1282> 21.04.2020.

[Tvardovskiy, Aleksandr. «Rabochiye tetradi 60-kh godov», Znamya, $\mathrm{N}^{\circ} 11<\mathrm{http} / /$ znamlit.ru/publication.php?id=1282> 21.04.2020]

Хрущев, Никита. «О культе личности и его последствиях. Доклад XX съезду КПСС», Известия ЦК КПСС, N³ <http://lib.ru/MEMUARY/HRUSHEW/kult.txt> 22.04.2020.

[KHrushchev, Nikita. «O kul'te lichnosti i ego posledstviyakh. Doklad KHKH s"yezdu KPSS», Izvestiya TSK KPSS, N³ <http://lib.ru/MEMUARY/HRUSHEW/kult.txt> 22.04.2020]

\section{Снежана Станкович}

\section{РАЗГРОМ РЕДАКЦИИ ЖУРНАЛА НОВЫЙ МИР ПОСЛЕ ПУБЛИКАЦИИ ОДНОГО ДНЯ ИВАНА ДЕНИСОВИЧА}

\section{Резюме}

Цель настоящей статьи - определить причины разгрома журнала Новый мир, той позиции, которую занимал журнал в 60 -е годы XX века как один из важнейших символов в эпоху оттепели. Особое внимание отведено решениям КПСС, повлиявшим на дальнейшее развитие искусства и определившим его.

В этой статье представлены документы, мемуары, дневниковые записи сотрудников Нового мира с целью указания на причины разгрома редакции А. Т. Твардовского в 1970 году. Отдельно подчеркиваются объективность, правдивость и критическое отношение редакции ко всем публикациям в журнале, из-за которых и был разгромлен Новый мир.

Ключевые слова: разгром редакции, Новый мир, Один день Ивана Денисовича, А. И. Солженицын, А. Т. Твардовский, оттепель. 